\title{
What can Hadean detrital zircon really tell us? A critical evaluation of their geochronology with implications for the interpretation of oxygen and hafnium isotopes
}

\author{
M.J. Whitehouse ${ }^{1}$, A.A. Nemchin ${ }^{2}$, R.T. Pidgeon ${ }^{2}$ \\ ${ }^{1}$ Swedish Museum of Natural History, Box 50007, SE-104 05 Stockholm, Sweden \\ ${ }^{2}$ Department of Applied Geology, Curtin University, Perth, WA 6845, Australia.
}

\section{Abstract}

Rare Hadean zircon grains represent the only direct sample of the Earth older than $4.0 \mathrm{Ga}$. As such, they have tremendous potential to illuminate our knowledge of this period of Earth's history for which there is no extant rock record. In this study we revisit the existing dataset, supplemented by new analyses, to identify those grains from which a robust age may be inferred. This rigorous filtering approach identifies four distinct zircon growth events in the Hadean between ca. $4.4 \mathrm{Ga}$ and $4.0 \mathrm{Ga}$, and allows a reassessment of conclusions made from the determination of the $\mathrm{O}$ - and Hf-isotope systematics in these grains. Notably, we find no firm evidence for involvement of supracrustal reservoirs in zircon genesis prior to $4.15 \mathrm{Ga}$ and, while our filtered Hf-isotope data support interpretations for a mafic protocrust, there are insufficient analyses to constrain its evolution accurately. Clearly, further work is required and needs to be conducted in a systematic manner that first seeks to establish both the age and homogeneity of any given grain before proceeding to other types of analysis.

\section{Introduction}

The continuous operation of some form of plate-recycling since at least 3.8 Ga (Shirey et al., 2008) has so effectively destroyed all vestiges of Earth's earliest crust that the only direct terrestrial evidence for the nature of the Hadean Earth comes from rare $>4.0$ Ga zircon grains preserved in much younger metasedimentary units, which presumably sampled contemporaneous extant (?exhumed) Hadean crust in the mid-Archean. While single xenocrystic zircon grains of Hadean age have been reported from the 
Acasta Gneiss in Canada (lizuka et al, 2006), the Itsaq Gneiss Complex in West Greenland (Mojzsis

and Harrison, 2003), localities in the North China Craton (Cui et al, 2013) and adjacent North Qinling Orogenic Belt (Diwu et al., 2013), together with a single detrital zircon occurrence in Tibet (Duo et al, 2006), the vast majority of Hadean zircon grains reported to date come from a small number of localities in the Yilgarn Craton (western Australia). Although individual occurrences have potential to yield important information about Hadean geodynamics, they are not amenable to detailed statistical treatment as presented herein. Hence we focus our study on the Yilgarn occurrences alone. Since their discovery in the mid-1980's (Froude et al., 1983; Shearer et al., 1985; Compston and Pidgeon, 1986), Hadean (i.e. $>4.0 \mathrm{Ga}$ ) zircon grains recovered from ca. $3.0 \mathrm{Ga}$ metasedimentary units in the Yilgarn Craton, have been the subject of intensive geochemical and isotopic investigation to constrain the nature of Earth's earliest crust and surface environment. Coinciding closely in time with the development of in situ analytical methods, primarily ion microprobe (or Secondary Ion Mass Spectrometry, SIMS) uranium-thorium-lead geochronology pioneered by the Australian National University group (Clement et al., 1977; Compston et al., 1984), Hadean zircon has been subject to an increasing diversity of analytical investigations, in many cases being chosen as the prime target for newly established methods, for example high-precision in situ SIMS measurements of oxygen isotopes (Valley, 2003),laser-ablation inductively-coupled mass spectrometry (LA-ICPMS) determination of hafnium isotopes (Hawkesworth and Kemp, 2006; Kemp et al, 2010; Harrison et al., 2005), and atomprobe tomography (Valley et al., 2014). Besides direct investigation of Hadean zircon grains, several analogue studies have attempted to correlate features of post-Hadean and even modern zircon (Grimes et al, 2007; Reimink et al., 2016) with those from the Hadean in order to infer a potential tectonic environment for the latter.

An exhaustive review of all the data obtained from Hadean zircon is beyond the scope of this paper. Instead, we undertake a rigorous reassessment of a subset of published data from studies which present sufficient information to do so, as well as a set of newly acquired data from the Jack Hills, reported here for the first time. Our primary goal is to define a set of criteria enabling identification of those zircon grains from which geochemical and isotopic data can be interpreted as a true record of the 
petrographic and geochemical conditions of their original crystallisation. We then use this filtered

dataset to revisit some of the more far-reaching conclusions drawn from the existing data in an attempt to reconcile conflicting views that have emerged regarding Hadean tectonics. Since the investigation of Hadean zircon is ongoing, these criteria should further enable researchers generating new data to identify pristine Hadean zircon.

\section{Hadean tectonics - a diversity of evidence, a dichotomy of interpretations}

Two principal approaches that have generally been used to investigate the Hadean are (i) the study of ancient ( $<4.4 \mathrm{Ga})$ detrital zircon and (ii) inferences from post-Hadean isotopic reservoirs. In addition, planetary analogues (e.g. Mars) have potential to yield important insights into the Earth's missing early history. However, despite in-depth, innovative direct and indirect studies, there remains considerable ambiguity about processes on the Hadean Earth and, notably, a dichotomy of models. On the one hand, several lines of evidence from the Jack Hills detrital zircon suite have been used to support the existence of modern-style plate tectonics with subduction and well-developed continental (-type) crust on the Earth as early as 4.4 - 4.5 billion years ago (Bell, et al., 2011; Bell et al., 2013; Bell et al.,2014; Cavosie et al., 2005; Cavosie et al., 2006; Harrison et al., 2008; Hopkins et al., 2008; Mojzsis et al., 2001; Peck et al, 2001; Wilde et al., 2001; Valley et al., 2002; Ushikubo et al., 2008;). These include: (1) stable isotope data, indicating that the original host rocks to the zircon incorporated a significant amount of material formed on or near the Earth's surface and subsequently transferred to a middle- to lower-crustal level where they melted to generate the host magmas from which zircon crystallised (Cavosie et al., 2006; Mojzsis et al., 2001; Peck et al, 2001; Wilde et al., 2001; Valley et al., 2002; Ushikubo et al., 2008); (2) inclusion assemblages, dominated by quartz with less abundant K-feldspar, plagioclase, muscovite, biotite, and phosphates, that are interpreted to have formed under relatively low geothermal gradient similar to that pertaining to modern subduction zones (Peck et al, 2001; Hopkins et al., 2010) ; (3) Ti-in-zircon temperatures and rare earth elements (Watson and Harrison, 2005; Harrison et al., 2008; Peck et al, 2001; Maas et al., 1992) signatures in some zircon grains that have been interpreted to indicate crystallisation of these grains from evolved melts; (4) LuHf systematics potentially indicating existence of an early formed reservoir, similar to continental 
crust in its degree of Lu depletion relative to Hf (Harrison et al., 2008; Blichert-Toft and Albarede, 2008).

Significant problems arise, however, when trying to extrapolate modern-style plate-tectonics into the Hadean. Plate-tectonics is characterised by production of isotopically juvenile basaltic melts at mid-ocean ridges, which are largely recycled back into the mantle on a relatively short time scale (tens to a few $100 \mathrm{Ma}$ ) at subduction zones. At the subduction zone, melting of both this crust and parts of the mantle above the subducting slab generates buoyant, felsic crust (ultimately the precursor to continents), resulting in an irreversible mantle-crust differentiation. Conversely, a number of observations suggest long-term (several 100 myrs) isolation of a Hadean "proto-crust", namely: (1) Lu-Hf systematics of the Jack Hills zircons, which shows no significant input of juvenile material into their source region (Kemp et al., 2010), and similar evidence for Hadean sources in Hadean Eoarchean TTG genesis from Acasta (Reimink et al., 2016; Bauer et al., 2017) and Greenland (Naeraa et al., 2012); (2) Pb-isotope systematics of Early Archaean rocks which require unusually radiogenic initial $\mathrm{Pb}$ compositions suggesting derivation from Hadean mafic protocrust (Kamber et al., 2003); (3) $\mathrm{Th} / \mathrm{Nb}$ systematics of mantle-derived rocks throughout geological time, pointing to a progressive development of the crust-mantle system instead of early-formed and voluminous continental crust (Collerson and Kamber, 1999); and (4) graphite inclusions discovered in some of Jack Hills zircons (Menneken et al., 2007; Nemchin et al., 2008; Bell et al., 2015) which are inconsistent with a granite source. These observations have been used to propose an alternative view of the Hadean Earth characterised by a less differentiated basaltic crust (or "stable lid") and an absence of modern-style plate tectonics (Kamber et al., 2005; Kramers, 2007; Griffin et al., 2014; Zeh et al., 2014; Kamber, 2015).

This apparent dichotomy of evidence needs to be taken into account when trying to formulate fully consistent models of the Hadean Earth. Consequently, proponents of subduction have to explain the apparent long-term isolation of Hadean crust while models excluding plate tectonics have to incorporate mechanisms that allow delivery of surface-derived materials to at least middle-low crustal levels. 
The underlying issue with the interpretation of Hadean zircon data that has resulted in the

existing diversity of opinions and models is the complexity of the studied zircon populations combined with a general lack of a comprehensive record of the analysed areas within the grains. This leads to difficulty in relating ages of specifically dated parts of the zircon grains to their $\mathrm{O}$ and $\mathrm{Hf}$ isotope systematics and trace element concentrations. Consequently, while in theory zircon provides the capability to establish a timeline for evolution of isotopic and chemical compositions prevailing during its formation, precise relationships between these compositions and ages are not very well constrained for the Hadean grains. This often precludes even determining accurate and precise crystallisation ages for Hadean zircon grains, which is a key prerequisite to extracting information about Hadean processes for several reasons. Firstly, a well-defined geochronological framework is needed to address the periodicity of magmatism during the Hadean, which clearly has implications for tectonic processes. Critically, is the continuum of ${ }^{207} \mathrm{~Pb} /{ }^{206} \mathrm{~Pb}$ ages, albeit with a number of peaks, observed in the Jack Hills zircon suite (e.g. Holden et al., 2009) real or an artefact of later resetting of the U-Pb system? If real, can this pattern be reconciled with tectonic/magmatic processes analogous to those discernible from the extant post-Hadean geological record? Secondly, accurate ages are required to calculate initial isotope compositions from the Lu-Hf system in the same dated growth phase of a zircon in order to avoid erroneous interpretations (e.g. Vervoort et al., 2016). Thirdly, accurate geochronology is essential to provide a minimum age for elevated $\delta^{18} \mathrm{O}$, which has been argued as supportive of a wet cool Earth (Valley et al., 2002), as well as to place age limits on the conditions recorded by inclusions in zircon (Hopkins et al., 2008).

The current lack of an unambiguous chronological framework stems largely from shortcomings of the $\mathrm{U}-\mathrm{Pb}$ systematics with currently achievable analytical precision. The U-Pb system in zircon is very commonly considered to be the geochronologist's "gold standard" (Ludwig, 1998), in part since it provides an internal validation of ages via concordance of the two independent uranium-based decay schemes in undisturbed zircon, ${ }^{235} \mathrm{U}$ decaying to ${ }^{207} \mathrm{~Pb}\left(\mathrm{t}_{1 / 2} \approx 4.47 \mathrm{Ga}\right)$ and ${ }^{238} \mathrm{U}$ decaying to ${ }^{206} \mathrm{~Pb}\left(\mathrm{t}_{1 / 2} \approx\right.$ $0.704 \mathrm{Ga}$ ). At both ends of the geological time-scale, however, the difference in decay rates of the two parent isotopes means that the concordia system becomes essentially one-dimensional, with only one 
of the decay schemes able to provide a relatively precise age. For very young zircon, only ${ }^{206} \mathrm{~Pb} /{ }^{238} \mathrm{U}$ ages are adequately precise due to the negligible ingrowth of ${ }^{207} \mathrm{~Pb}$ relative to ${ }^{206} \mathrm{~Pb}$, while for very old zircon, the subject of this paper, rapid ingrowth of ${ }^{207} \mathrm{~Pb}$ relative to ${ }^{206} \mathrm{~Pb}$ results in a system in which ${ }^{207} \mathrm{~Pb} /{ }^{206} \mathrm{~Pb}$ ages are the most precise. Since the part of the conventional concordia curve pertaining to the early Earth is essentially sub-horizontal (or sub-vertical in the equivalent inverse Tera-Wasserburg coordinates), detection of ancient $\mathrm{Pb}$-loss in Hadean and Eoarchean zircon is often precluded because a small change in $\mathrm{Pb} / \mathrm{U}$ ratios associated with $\mathrm{Pb}$-loss is encompassed by large analytical uncertainties, particularly those associated with relatively low precision in situ methods, which have dominated the geochronology of Hadean zircon (Fig. 1). Furthermore, given the absence of preserved crustal domains from the Hadean, even informed speculation from other methods/materials about the timing of events (e.g. tectonothermal or impact related) that may have caused Pb-loss in the detrital zircon populations, is impossible - indeed, within the limits of currently available methods, the very existence of such events is not only unknown but essentially unknowable.

\section{Geology of the Yilgarn occurrences}

Old, > 3.9 Ga, zircon grains are found at five different localities within the Yilgarn Craton (Froude et al., 1983, Compston and Pidgeon, 1986; Thern and Nelson, 2012; Wyche et al., 2004) (Fig. 2). Two of these are metasedimentary belts at Mt. Narryer and Jack Hills, consisting of alternating metaconglomerate, meta-sandstone and meta-pelite layers occurring as inliers within the Narryer Gneiss terrane (Spaggiari, 2007; Spaggiari et al., 2007). This terrane, which is the oldest segment of the crust in the north-west part of the craton, is composed mainly of a mixture of ca. 3.7 and $3.3 \mathrm{Ga}$ gneisses with some minor mafic to ultramafic rocks and anorthosites (Kinny et al, 1988; Kinny et al., 1996; Myers, 1993; Myers and Williams, 1985).

A third location occurs within the Southern Cross Terrane to the south-south-east of the Narryer Gneiss terrane. This is a region within the Yilgarn Craton that consists of several greenstone belts, some of which are as old as about $3.0 \mathrm{Ga}$, while others are believed to represent a younger $(\sim 2.7 \mathrm{Ga})$ succession. The greenstone belts are surrounded by late Archaean granites. Old (> 3.9 Ga) detrital 
zircons have been found in the quartzites and associated quartz rich metasedimentary rocks in the Illaara and Maynard Hills greenstone belts (Thern and Nelson, 2012; Wyche et al., 2004).

Finally two zircon grains have been identified as xenocrysts in two late Archaean granite-gneisses. One was found in a sample collected near Churla Well within the Narryer Gneiss terrane and another comes from the Beeara gneiss complex of the Murchison Terrane (Nelson et al., 2000). Both grains exhibit heterogeneous ages from multiple analytical spots that nevertheless are in excess of $3.9 \mathrm{Ga}$.

\section{The Jack Hills zircon}

The Jack Hills detrital zircon population is the most studied group containing Eoarchean and Hadean $(>4.0 \mathrm{Ga})$ zircon. As a result it is the only group of Hadean grains sufficiently large to permit a statistically robust assessment of the applicability and limitations of zircon mineralogical, chemical and isotopic characteristics necessary to formulating models of Earth's early evolution. Importantly, the question of source rocks of these zircon grains has rarely been raised and never addressed in any comprehensive way, despite the extensive chemical and isotopic studies of this population. It is generally either directly assumed or implied that these grains are magmatic in origin. For example, discussion of the $\mathrm{Ti}$ in zircon thermometer has normally developed around the question of whether the data reflect crystallization from low temperature granitic melts or a tendency of zircon to crystallise late in the magmatic evolution (Harrison et al., 2008; Nutman et al., 2006), with the observed Ce anomaly suggested to indicate an oxidised source for the magma (Trail et al., 2007). Likewise, enrichment in LREE observed in many Jack Hills grains has been discussed in terms of a feature imparted by crystallisation from felsic melts (Peck et al., 2001), although secondary processes modifying original (magmatic) zircon have also been suggested (Whitehouse and Kamber, 2002; Hoskin, 2005; Bell et al., 2016). The main disagreement in the interpretation of Hf isotope data is whether it reflects felsic or mafic protoliths to the melts that crystallised Jack Hills zircon (Harrison et al., 2008; Blichert-Toft and Albarede, 2008; Kemp et al., 2010). Oxygen isotopes are generally discussed in the context of the melt from which the zircon crystallised originating (or not) from 
sedimentary rocks that have experienced significant recycling under low temperature, water-rich al., 2006).

Zircon crystallisation is ubiquitous in igneous rocks (both volcanic and plutonic) ranging in composition from granite to diorite as well as some alkaline rocks. While zircon can also crystallise from some late residual fractions of gabbroic intrusions, it is comparatively rare in these rocks. Other lithologies with significant zircon are amphibolite to granulite facies metamorphic rocks with a pelitic to psammitic origin, as well as metamorphosed felsic igneous rocks and migmatites. There are only comparatively rare occurrences of zircon in some mafic granulites as well as high pressure metamorphic rocks. In addition, infrequent occurrences of hydrothermal and diagenetic to low grade metamorphism zircon have been reported in the literature. Most of this information is summarised in the special zircon volume of Reviews in Mineralogy and Geochemistry (e.g. Hoskin and Schaltegger, 2003; Corfu et al. 2003 and references therein).

The limited discussion of the origin of the Jack Hills zircon grains found in the literature is based on the trace element geochemistry of the grains rather than an analysis of internal structures revealed by imaging techniques such as BSE and CL. This approach relies on an assumption that concentrations of some trace elements such as REE, Y, Hf, $\mathrm{U}$ and Th vary systematically between zircon crystallising in different rock types (e.g. Belousova et al., 2002; Grimes et al., 2007; Grimes et al., 2015, Chapman et al., 2016). However, several studies have indicated significant difficulties in distinguishing zircon origin based on their trace element content due to an overall similarity or at least substantial overlap of the composition of zircon from different rocks (Hoskin and Ireland, 2000; Hoskin and Schaltegger, 2003).

Analogous to the chemical overlap between zircon from diverse types of sources, zircon of different origin show some similarity in their internal structures. Consequently a combination of internal structure studies with trace element analysis appears to be the most promising approach to make a link 
between zircon grains and their source rocks. However, none of the Jack Hills zircon studies provide grains as well as addressing the question of their origin. In fact, most descriptions of internal structures in the Jack Hills population are superficial and do not highlight potential complexity either between or within potential populations.

Figure 3 shows a range of internal structures common in Jack Hills zircon, excluding some frequent secondary features, such as blurring of CL zoning grading into complete homogenisation of CL response across the grains as well as formation of irregular domains, often with curved boundaries inside the grains. Images A, B and C in Figure 3 show fine concentric zoning commonly attributed to zircon crystallising from the melt (Corfu et al., 2003). Thicker, but still concentric bands exhibited by grains $\mathrm{D}, \mathrm{E}$ and $\mathrm{F}$ can be also interpreted as magmatic in origin (Corfu et al., 2003). In contrast, internally homogenous sector zones in grains $\mathrm{J}, \mathrm{K}$ and $\mathrm{L}$ are often found in high grade metamorphic rocks (Corfu et al., 2003, Vavra et al., 1996; Vavra et al., 1999). Similarly some of the fir-tree to sector to "cross-bedded" zoning in grains $\mathrm{G}, \mathrm{H}$ and I is often interpreted as solid state zircon crystallisation associated with high grade metamorphism (Vavra et al., 1996; Vavra et al., 1999), although these features can be also attributed to crystallization in late magmatic or anatectic melts. Similar zoning is also visible in the tips of grains $\mathrm{C}$ and $\mathrm{F}$. Grains $\mathrm{M}, \mathrm{N}$ and $\mathrm{O}$ show complex internal structures that are difficult to link to a single process, but importantly they do not appear to represent simple crystallisation from a magma.

The presence of internal complexity in Jack Hills zircon questions the validity of some constraints related to early Earth evolution made on the basis of zircon isotope studies, especially in the absence of a clear link between most of the isotope data and the internal structures of the analysed grains. Indeed, a large proportion of grains in the population exhibit features that could be interpreted as metamorphic in origin. It is ambiguous whether a heavy oxygen isotope signature, if confirmed in these "metamorphic" grains can still be interpreted as representing recycling of altered (e.g. sedimentary) source rocks. Equally, interpretations of $\mathrm{Hf}$ isotope systematics in such complex grains as reflecting the composition of melt sources in the Hadean should be treated with caution because the 
assigned age on which modeling is based may in some cases be an artifact of $\mathrm{Pb}$-loss and not a true crystallisation age.

There is no recognized consistent or correlated behavior between ages and type of internal structure of the grains, indicating that either both "magmatic" and "metamorphic" internal structures are present in the grains spanning entire range of ages observed in Jack Hills population or that the systematic behavior is masked by the earlier discussed difficulties with the estimation of accurate ages of the large number of grains in the population.

\section{Filtering of the ancient data set 1: geochronology}

Before addressing the significance of the dataset reviewed here, it is necessary to comment on the choice of ages in literature data and outline our preferences, which will then be applied to all data. As discussed above, ${ }^{207} \mathrm{~Pb} /{ }^{206} \mathrm{~Pb}$ ages in ancient zircon are generally more precise than ${ }^{206} \mathrm{~Pb} /{ }^{238} \mathrm{U}$ ages and in fact for typical SIMS levels of analytical uncertainty, this is the case for anything older than Mesoproterozoic. As a result, studies of ancient detrital zircon populations generally quote only ${ }^{207} \mathrm{~Pb} /{ }^{206} \mathrm{~Pb}$ ages, merely using the ${ }^{206} \mathrm{~Pb} /{ }^{238} \mathrm{U}$ age to assess whether an analysis is, within uncertainty, concordant. When only a single analysis is under consideration, this is the only approach available. Given the potential ambiguity of a single age obtained from any ancient zircon grain, as discussed above, we have chosen here to restrict our assessment of the Hadean zircon population to those grains on which two or more spot analyses have been performed (Table 1). In addition to this criterion, we have also restricted the dataset to those grains yielding ages in excess of $3.8 \mathrm{Ga}$ (i.e. early Eoarchean and Hadean). These criteria limit the data included in our study to those in Table 1, which lists 451 individual U-Pb spot analyses that have been performed on 142 zircon grains together with their source. Of these data, 133 analyses on 54 grains are presented here for the first time (analytical methods pertaining to these are summarised in Table 1).

The data filtered according to these criteria are subdivided into three basic groups. Group 1 grains are those from which all analyses are concordant within stated uncertainties and consistent in age so that 
they can be combined to yield a concordia age (sensu Ludwig, 1998; Table 2). Group 2 grains yield

multiple analyses that are all concordant within error but not all are consistent in age. Two subgroups are defined within group 2, group 2a being those grains from which some data points are consistent in age and can therefore be combined into a concordia age (Table 2), while group $2 \mathrm{~b}$ are those from which none of the analyses are consistent in age and yield only single concordant age(s). Group 3 grains are those from which multiple analyses have yielded some discordant analyses. This group is subdivided into group 3 a comprising grains from which some analyses are both concordant and consistent in age, group $3 \mathrm{~b}$ with some concordant analyses that can yield single age(s) and group $3 \mathrm{c}$ in which none of the analyses are concordant.

For consistency in these calculations, we have throughout used a probability (p) of 0.05 to assess whether the combined data yield a statistically significant concordia and/or weighted average ${ }^{207} \mathrm{~Pb} /{ }^{206} \mathrm{~Pb}$ age. We have also included decay constant uncertainties in all age calculations. Following the recommendations of Ludwig (1998), we consider the combined mean square of the weighted deviates (MSWD) of concordance and equivalence as the most appropriate measure of the significance of a concordia age and have presented this value along with the separate MSWD and probability values for equivalence and concordance in Table 2. Uncertainties on concordia ages in tables and plots are presented at the $2 \sigma$ level except when the probability of fit for a concordia age and/or weighted average ${ }^{207} \mathrm{~Pb} /{ }^{206} \mathrm{~Pb}$ age is less than 0.05 , in which case we present ages at the $95 \%$ confidence level

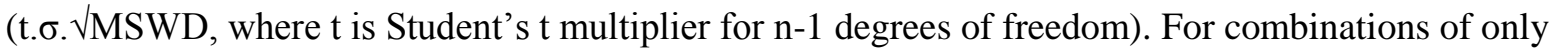
two data points with $\mathrm{p}<0.05, \mathrm{t}=12.5$, which results in relatively imprecise ages. In such cases, it could be argued that the oldest concordant ${ }^{207} \mathrm{~Pb} /{ }^{206} \mathrm{~Pb}$ age, which will be considerably more precise, should be substituted (i.e. the grain reassigned to group $2 \mathrm{~b}$ or group $3 \mathrm{~b}$ ), but for this compilation and data analysis, our preference is to retain them as combined ages, albeit at lower precision.

Results of the data filtering exercise are presented in probability density plots (PDPs) in Fig. 4. The unfiltered dataset comprises a total of 451 analyses, performed on 142 grains, whose ${ }^{207} \mathrm{~Pb} /{ }^{206} \mathrm{~Pb}$ ages are plotted in Fig. 4a irrespective of concordance and filtered for $<10 \%$ and $<2.5 \%$ discordance, resulting in remaining populations with $n=335$ and $n=214$ analyses, respectively. The PDP shows a 
noisy pattern with several prominent peaks, notably at ca. $4.35 \mathrm{Ga}, 4.15 \mathrm{Ga}, 4.1 \mathrm{Ga}$ and $4.0 \mathrm{Ga}$

separated by periods characterised by smaller age peaks. This general pattern is essentially little changed by the discordance filtering, which reflects the dominance of recent Pb-loss in the Jack Hills population evident from the concordia diagram (Fig 5), since such Pb-loss will have only a minimal effect on ${ }^{207} \mathrm{~Pb} /{ }^{206} \mathrm{~Pb}$ ages.

Filtering on the basis of limiting the degree of discordance (Nemchin and Cawood, 2005), while a common practice in detrital zircon populations, for example at the 5 or $10 \%$ level, is additionally complicated in the available Hadean zircon data set by the variable precision of $\mathrm{Pb} / \mathrm{U}$ ages obtained by SIMS analyses. Expected uncertainties $(1 \sigma)$ on ${ }^{207} \mathrm{~Pb} /{ }^{206} \mathrm{~Pb}$ and ${ }^{206} \mathrm{~Pb} /{ }^{238} \mathrm{U}$ ratios are typically around $0.5-1 \%$ and $1-2 \%$ respectively, the former determined largely by counting statistics, the latter influenced also by the external uncertainty propagated from measurement of the zircon standards utilised for $\mathrm{Pb} / \mathrm{U}$ calibration. A plot of the uncertainty on ${ }^{207} \mathrm{~Pb} /{ }^{206} \mathrm{~Pb}$ against that of ${ }^{206} \mathrm{~Pb} /{ }^{238} \mathrm{U}$ for all of the analyses considered in this review $\left(n=451\right.$; Fig. 6 a) shows that while ${ }^{207} \mathrm{~Pb} /{ }^{206} \mathrm{~Pb}$ ratios are similar in all studies, there is a much greater range of uncertainty in ${ }^{206} \mathrm{~Pb} /{ }^{238} \mathrm{U}$ ratios, with a substantial number of analyses having a precision worse or much worse than is normally expected. Some of this excess uncertainty may be explained by inhomogeneity in grains caused by recent $\mathrm{Pb}$-loss on a scale less than a single analysed volume, and filtering of the data set to include only those grains that are concordant within $2 \sigma$ error eliminates most, but not all of the grains with higher uncertainty $(n=257$; Fig, 6b). Distinct sub-vertical arrays in $\mathrm{Pb} / \mathrm{U}$ uncertainty reflect individual analytical sessions and it is clear that that some of these simply have worse precision for reasons that are not discernible from the relevant published methodological descriptions.

By utilising our categorisation of the multiply analysed grains and calculating concordia ages, additional filtering of the dataset results in increasing confidence in the remaining age peaks at the expense of increasing rejection of analyses. The PDP shown in Fig 4b combines concordia ages calculated from 2 or more analyses with single oldest concordant ages, preserving information from 120 zircon grains ( $86 \%$ of the original dataset) but only 184 analyses (41\%). The four prominent peaks identified in the unfiltered and discordance filtered data remain, but there is a slight suppression of the 
noise between these peaks. If only concordia ages from two or more analyses are considered, the number of grains retained drops to $45(39 \%)$, corresponding to $112(25 \%)$ analyses and much of the noise between the prominent peaks is eliminated. The most extreme filtering, illustrated in Fig 4d, considers only those grains from which Concordia ages have been obtained from three or more analyses, limiting the retained dataset to 46 analyses from 13 grains (both $\sim 10 \%$ of the original grain/analysis dataset). At this level of rejection the four prominent peaks identified earlier remain, with small shoulders on the lower age side of the oldest $4.37 \mathrm{Ga}$ peak and the higher age side of the ca. 4.1 Ga peak indicating the possibility of two additional age populations.

\section{Filtering of the ancient data set 2: oxygen isotopes}

Of the 46 grains where Concordia ages from two or more analyses have been obtained, 25 have been analysed multiple times for their oxygen isotope composition (Table 3), permitting calculation of average $\delta^{18} \mathrm{O}$ (expressed relative to Vienna Standard Mean Ocean Water, V-SMOW; Table 4). Four of the grains show a scatter in the $\delta^{18} \mathrm{O}$ values of individual analyses resulting in high MSWD and low probability of the averages, indicating oxygen isotope complexity on the intra-grain level; these four grains are therefore omitted from further discussion. Three grains have average $\delta^{18} \mathrm{O}$ values less than $5 \%$ and although two of these overlap within the $2 \sigma$ uncertainty limit on mantle-derived zircon, the third, which is in fact the oldest grain in this compilation, is significantly lower than the mantle derived zircon range, indicating a possibility either of:(1) processes similar to those involved in alteration of modern basaltic crust by sea water affecting the igneous precursor of the three zircon grains or (2) zircon alteration postdating its formation that is not detectable in analyses of the U-Pb system. Only one grain, with an age of $4153 \mathrm{Ma}$, has an average $\delta^{18} \mathrm{O}$ value of $7.8 \pm 0.4 \%$ (Fig. 7), which might provide evidence of recycling of supracrustal rocks or melting of hydrated upper oceanic crust (or its Hadean analog) with elevated $\delta^{18} \mathrm{O}$ (Muehlenbachs and Clayton, 1976). The remainder of the oxygen isotope data can be viewed as forming a continuum between $5.4 \pm 0.2$ and $6.6 \pm 0.3 \%$ or falling into two separate groups one comprising 5 grains with a mean $\delta{ }^{18} \mathrm{O}$ value of $5.6 \pm 0.2 \%$ and the other group comprising 12 grains with a mean of $6.1 \pm 0.1 \%$. The first value matches that of mantle derived zircon, while the second, though slightly elevated, is still within the range attainable by 
a magmatic fractionation (Cavosie et al., 2005). There is no apparent correlation between the age and oxygen isotope composition of the grains, although two grains older than $4.3 \mathrm{Ga}$ both show $\delta^{18} \mathrm{O}$ values less than $5 \%$, which is intriguing given both the general paucity of low d18O grains in the geological record (Valley et al., 2005) and their documentation from other Eoarchean and Hadean samples (Heiss et al., 2011; Reimink et al., 2014). The zircon with an elevated $\delta^{18} \mathrm{O}$ is one of several grains making up the age group at $\sim 4.15 \mathrm{Ga}$, suggesting that if its $\delta^{18} \mathrm{O}$ does provide evidence for interaction with supracrustal oxygen isotope reservoir(s), this is not a ubiquitous feature of this time interval.

\section{Filtering of the ancient data set 3: hafnium isotopes}

A general problem in the investigation of Hf isotope systematics in complex zircon grains, such as the Jack Hills detrital population, is assigning correct U-Pb age for initial $\varepsilon_{\mathrm{Hf}}$ estimation and plotting $\varepsilon_{\mathrm{Hf}}$ vs. time (Vervoort and Kemp, 2016). Taking into account the overall heterogeneity of the Jack Hills zircon grains, using single SIMS U-Pb ages combined with the results of ICP MS Hf analyses (e.g. Harrison et al., 2005) is problematic as the volume of material used by two techniques is dramatically different and the possibility of sampling across zones with different crystallisation age cannot be discounted (Harrison et al, 2008). Furthermore, as discussed above, within the typical uncertainty limits of in situ methods it is common that even in a single growth zone, variable degrees of essentially undetectable ancient $\mathrm{Pb}$-loss can result in ages that appear concordant but inaccurately reflect crystallisation age. In order to try to avoid these complications, Kemp et al (2010) measured Pb isotope ratios concurrently with $\mathrm{Hf}$ isotopes in a single analysis, with within-run monitoring of the ${ }^{207} \mathrm{~Pb} /{ }^{206} \mathrm{~Pb}$ age allowing identification of mixed zones. This method resulted in data set that enabled Kemp et al. (2010) to draw more valid conclusions about the evolution of Hf isotopes in the Hadean and early Archean. In particular, these authors were able to define an average Hf isotope evolution through time along a trend with a Lu/Hf ratio characteristic of mafic crust, with no obvious input of juvenile, mantle-derived material, which they interpreted as more consistent with tectonic models involving a stagnant crustal lid (e.g. Kamber et al., 2005) than those involving plate boundary interactions akin to modern plate-tectonics (e.g. Harrison et al., 2005). While clearly a major advance 
in the interpretation of Hf isotopes in the Jack Hills zircon suite, the Kemp et al. (2010) dataset still

displays potential analytical artefacts, with steeper sub-trends that may reflect some residual degree of inaccurate age assignment, especially in the case of undetectable ancient Pb-loss. Clearly, using ${ }^{207} \mathrm{~Pb} /{ }^{206} \mathrm{~Pb}$ ages obtained by ICP MS in conjunction with Hf isotope analyses, whether by concurrent (Kemp at el. 2010) or the recently developed split-streaming method (Fisher et al., 2014), has issues with sample volume. Specifically for the Jack Hills zircon grains that are documented to be inhomogeneous with respect to age, a larger sampled volume increases the possibility of underestimating the age (Fig. 8) by either mixing of different domains with significantly different ages or inability to detect ancient Pb-loss.

Figure 8 shows the results of filtering of the existing Hf isotope data set by selection only of zircon grains that show U-Pb age consistency from multiple SIMS analyses. Of the 68 zircon grains analysed for Hf isotopes by Kemp et al. (2010), only five are grains which have yielded concordia ages from two or more consistent SIMS analyses, with a further two grains having multiple concordant analyses from which the oldest concordant grain age has been selected. In all cases, the selected SIMS age, whether a concordia age or oldest concordant age, is the same or older that the concurrently determined ${ }^{207} \mathrm{~Pb} /{ }^{206} \mathrm{~Pb}$ age, and for these filtered grains, the $\mathrm{Hf}$ isotope result is plotted using the SIMS age. Using this limited subset of the Hf data to generate a meaningful trend line is impossible, although they remain broadly consistent with the trend of the complete data set.

\section{Comparison of filtered data and previously reported $\mathrm{U}-\mathrm{Pb}, \mathrm{O}$ and $\mathrm{H} f$ results}

Several publications present probability distribution and/or histogram plots of ${ }^{207} \mathrm{~Pb} /{ }^{206} \mathrm{~Pb}$ ages of Jack Hills zircon based on significantly different number of analyses ranging from a few tens of grains older than 3.8 Ga analysed (e.g. Cavosie et al., 2004) to a few thousand (e.g. Holden et al., 2009; Trail et al., 2013). The latter shows a continuous (almost bell shaped) distribution of ages between 4.37 and $3.85 \mathrm{Ga}$ with a maximum at about $4.05 \mathrm{Ga}$ (Figure 9). This contrasts sharply with the three main peaks between about 4.2 and $4.0 \mathrm{Ga}$ identified in the filtered data set presented here. It is possible that this comparison is invalidated by the significantly different number of analyses used to constrain these 
plots. However, the probability density distribution of ${ }^{207} \mathrm{~Pb} /{ }^{206} \mathrm{~Pb}$ ages presented by Cavosie et al.

(2004) is based on a number of analyses very similar to our filtered data set, but shows a distribution pattern more similar to that of Holden et al. (2009), suggesting that the apparently continuous distribution appearing in ages of Jack Hills zircon population can be related to the unrecognised analysis of mixed age domains with different and/or partly disturbed ages. Regardless of preferences in the interpretation of the observed discrepancy between age distribution patterns, the existence of this discrepancy highlights that a correct understanding of age patterns exhibited by the Jack Hills detrital population requires careful additional analytical work guided by CL images of the grains, with the goal of identifying convincingly different aged domains with internally consistent behaviour of U$\mathrm{Pb}$ system within a statistically significant number of individual zircon grains.

Filtered oxygen isotope data can be compared with the set of results presented by Cavosie et al. (2005), which has also been rigorously filtered based on the post-analysis imaging of analytical pits to eliminate analyses that intersected fractures, inclusions and other imperfections. In contrast to the published data (including that of Cavosie et al., 2005) the analyses remaining after filtering presented here generally lack $\delta^{18} \mathrm{O}$ values above $6.5 \%$ (Figure 10). A striking exception is a single grain with a very heavy isotope oxygen composition falling (according to the Cavosie et al., 2005 definition) into the "altered zircon" field. The nature of this heavy oxygen is unclear and difficult to interpret based on just a single grain that shows such an anomalous composition. The majority of the filtered analyses fall in the gap between "mantle zircon" and "supracrustal zircon" of Cavosie et al. (2005), whereas a significant number of published analyses show either lower $\delta^{18} \mathrm{O}$ values around 5.5-6.0\%o (e.g. Trial et al., 2007) or around 7.0\% (Cavosie et al., 2005). It is also important to note that all data sets contain some zircon grains with very low $\delta^{18} \mathrm{O}$ values near $4.0 \%$, which suggest that even $\delta^{18} \mathrm{O} \approx 5.5 \%$ values could result from a secondary alteration process(es) responsible for a decrease in $\delta^{18} \mathrm{O}$, rather than representing primary oxygen composition of studied grains.

Filtering of the Hf data results in just a very few analytical points that can be considered reliable (Figure 11). This small number of points makes it difficult to constrain any trends on $\varepsilon_{\mathrm{Hf}} \mathrm{vs}$. age diagram with any degree of confidence and clearly indicate the need for additional analytical work. 
Nonetheless, the small dataset lacks positive $\varepsilon_{\mathrm{Hf}}$ values that are common in some other studies of $\mathrm{Hf}$ absent in the filtered data are results with very negative $\varepsilon_{\mathrm{Hf}}$ values, commonly attributed to the upper continental crust sources.

\section{Conclusions}

Based on a rigorous filtering of the available $\mathrm{U}-\mathrm{Pb}, \mathrm{O}$, and $\mathrm{Hf}$ isotopic data (both previously published and newly presented data), it is clear that only a rather small subset can be used to confidently place constraints on timing and processes in the Hadean. Specifically, of the already limited selection of 142 zircon grains admissible to our study on the basis of their having been analysed with at least two spots, only 45 grains yield consistent ages, which drops to only 13 grains if the additional criterion that the Concordia ages require at least three analyses is applied. This filtering yields robust groups of ages at ca. $4.37 \mathrm{Ga}, 4.15 \mathrm{Ga}, 4.10 \mathrm{Ga}$ and $4.02 \mathrm{Ga}$, which we interpret to represent likely zircon growth events during the Hadean, although the nature of these events remains obscure, for example whether they represent significant episodes of felsic crust generation, limited pockets of evolved magma in an essential mafic protocrust, a result of impact melt generation, a profound metamorphic resetting event, or several of these processes. Applying our filtering criteria to other diagnostic isotope systems commonly applied to Hadean zircon, we find that only a handful of the determined $\delta^{18} \mathrm{O}$ values (also only admitted to the study when they have been analysed more than once in a given grain) are backed up by "robust" geochronology and of these, only one is elevated out the range of values that could be attributed to magmatic fractionation, possibly reflecting interaction with a supracrustal reservoir at 4.15 Ga. No older grains unambiguously support such interaction, regardless of the robustness of their ages. For the Lu-Hf system in zircon, accurate age determination is essential to the calculation of initial ratios, which may then be used potentially to infer tectonic environments, for example in the Hadean, continental-type or mafic protocrust. Applying our age filtering to the dataset produced by Kemp et al. (2010) with ages modified to those from multiple SIMS analyses instead of the slightly younger concurrently acquired LA-ICPMS ages, only five grains are retained, of which only one meets our most rigourous criteria of at least three spot $\mathrm{U}-\mathrm{Pb}$ age analyses. While broadly consistent 
with the previous interpretation of a mafic protocrust, these data are not amenable to calculation of

source $\mathrm{Lu} / \mathrm{Hf}$ ratios. Given that a large proportion of the geochronological data obtained from the Jack Hills detrital zircon suite are barely (or not) fit for the purpose to which they are being used, we recommend that future studies follow a protocol of grain imaging by CL and/or BSE and careful, multiple spot in situ $\mathrm{U}-\mathrm{Pb}$ analysis in order to provide a rigorous geochronological framework prior to embarking on further isotope work and consequent interpretations. In this regard, the recently developed SIMS ion imaging method for visualising full intra-grain U-Th-Pb systematics (e.g. Bellucci et al. 2016) provides an additional discriminatory tool. We stress that our call for a rather laborious approach does not preclude the use of a rapid pre-screening method to identify particular age groups of interest, but ages obtained by such methods need to be confirmed by such a protocol before being used for other purposes. We note that studies of detrital zircon in general are commonly plagued by similar concerns to those outlined herein for the Hadean zircon suite and our recommendations are equally relevant to these studies.

Finally, we consider it important not to view studies of the Hadean detrital zircon populations in isolation, but to consider important potential analogues with zircon in Eoarchean and Hadean rocks that retain their petrographic context, hence permitting much more objective petrogenetic models to be constructed. However, to date, overlap with these examples is limited to the youngest part of the Hadean detrital zircon spectrum and changes in the tectono-magmatic and/or impact regime of the earliest Earth may render such comparisons irrelevant for the earliest zircon. Zircon remains unique in providing a "date-stamped" record for Hadean geochemical evolution, especially, as considered in this review, oxygen and hafnium isotopes, but these can only be assigned significance if/when the ages are accurate. Equally important constraints on the evolution the Hadean Earth come from other, albeit less chronologically precise, geochemical and isotopic studies of both ancient and modern rocks together with planetary analogues. Only by synthesising and reconciling all of the available data will progress be made in understanding the true nature of Earth's first half billion years. 


\section{Acknowledgements.}

The authors are grateful to Vickie Bennett and Tony Kemp for inspiring this work through their invitation to present a keynote address at the Montreal Goldschmidt conference, to the editors of Gondwana Research for commissioning this review paper and their patience during its lengthy gestation period, and to jounal reviewers Jesse Riemink and Nick Roberts for their insightful suggestions for improvement. M.J.W. and A.A.N. acknowledge the support of grants from the Swedish Research Council (2012-4370) and the Knut and Alice Wallenberg Foundation (2012.0097). Lev Ilyinsky and Kerstin Lindén are thanked for assistance with SIMS analyses undertaken at the NordSIMS facility in Stockholm of which this is publication number 517.

\section{References}

Bauer, A.M., Fisher, C.M., Vervoort, J.D. and Bowring, S.A., 2017. Coupled zircon Lu-Hf and U-Pb isotopic analyses of the oldest terrestrial crust, the $>4.03 \mathrm{Ga}$ Acasta Gneiss Complex. Earth and Planetary Science Letters, 458, pp.37-48.

Bell E.A. and Harrison T.M. (2013). Post-Hadean transitions in Jack Hills zircon provenance: a signal of the late heavy bombardment? Earth Planet. Sci. Lett. 364, 1-11.

Bell E.A., Boehnke P., and Harrison T.M. (2016). Recovering the primary geochemistry of Jack Hills zircons through quantitative estimates of chemical alteration. Geochimica et Cosmochimica Acta 191, 187-202.

Bell E.A., Harrison T.M., McCulloch M.T. and Young E.D. (2011). Early Archean crustal evolution of the Jack Hills zircon source terrane inferred from $\mathrm{Lu}-\mathrm{Hf},{ }^{207} \mathrm{~Pb} /{ }^{206} \mathrm{~Pb}$, and $\delta^{18} \mathrm{O}$ systematics of Jack Hills zircons. Geochim. Cosmochim. Acta 75, 4816-4829.

Bell E.A. Harrison, T.M., Koh, I.E., Young, E.D. (2014). Eoarchean crustal evolution of the Jack Hills zircon source and loss of Hadean crust. Geochim. Cosmochim. Acta, 146, 27-42.

Bell E.A., Boehnke P., Harrison, T.M. and Mao, W.L. (2015). Potentially biogenic carbon preserved in a 4.1 billion-year-old zircon. Proceedings of the National Academy of Sciences 112(47),1451814521.

Bellucci, J.J., Whitehouse, M.J., Nemchin, A.A., Snape, J.F., Pidgeon, R.T., Grange, M., Reddy, S.M., Timms, N. (2016). A scanning ion imaging investigation into the micron-scale U-Pb systematics in a complex lunar zircon. Chemical Geology 438, 112-122.

Belousova, E.A. Griffin, W.L. O'Reilly, S. Y. Fisher, N.I. (2002). Igneous zircon: trace element composition as an indicator of source rock type, Contrib Mineral Petrol. 143, 602-622

Blichert-Toft, J., Albarède, F. (2008). Hafnium isotopes in Jack Hills zircons and formation of the Hadean crust, Earth Planet. Sci. Lett. 265, 686-702 
Cavosie, A. J., Wilde, S. A., Liu, D., Weiblen, P. W., \& Valley, J. W. (2004). Internal zoning and U$\mathrm{Th}-\mathrm{Pb}$ chemistry of Jack Hills detrital zircons: a mineral record of early Archean to Mesoproterozoic (4348-1576Ma) magmatism. Precambrian Research 135, 251-279.

Cavosie A.J., Valley J.W., Wilde S.A. and E.I.M.F. (2005). Magmatic $\delta^{18} \mathrm{O}$ in 4400-3900 Ma detrital zircons: a record of the alteration and recycling of crust in the Early Archean. Earth Planet. Sci. Lett. 235, 663-681.

Cavosie A.J., Valley J.W., Wilde S.A. and E.I.M.F. (2006). Correlated microanalysis of zircon: trace element, $\delta^{18} \mathrm{O}$, and $\mathrm{U}-\mathrm{Th}-\mathrm{Pb}$ isotopic constraints on the igneous origin of complex $>3900 \mathrm{Ma}$ detrital grains. Geochim. Cosmochim. Acta 70, 5601-5616.

Chapman, J.B., Gehrels, G. E., Ducea, M. N. Giesler, N. Pullen, A. (2016). A new method for estimating parent rock trace element concentrations from zircon, Chemical Geology 439, 59-70

Clement, S.W.J., Compston, W.,Newstead, G. (1977). Design of a large, high resolution ion microprobe. Proceedings of the International Secondary Ion Mass Spectrometry Conference. Springer-Verlag. p. 12.

Collerson, K.D. and Kamber, B.S. (1999). Evolution of the continents and the atmosphere inferred from Th-U-Nb systematics of the depleted mantle. Science, v. 283, p. 1519-1522.

Compston, W. \& Pidgeon, R.T. (1986). Jack Hills, evidence of more very old detrital zircons in Western Australia. Nature 321, 766-769.

Compston, W., Williams, I.S., Meyer, C. (1984). U-Pb geochronology of zircons form lunar Breccia 73217 using a sensitive high mass-resolution ion microprobe. Journal of Geophysical Research: Supplement 89: B525-B534.

Corfu, F., Hanchar, J.M., Hoskin, P.W.O. Kinny, P. (2003). Atlas of zircon textures, Reviews in Mineralogy and Geochemistry 53 (1), 469-500

Dunn S.J., Nemchin A.A., Cawood P.A., and Pidgeon R.T. (2005). Provenance record of the Jack Hills metasedimentary belt: source of the Earth's oldest zircons. Precambrian Research 138(3) 235254.

Fisher, C.M., Vervoort, J.D. and DuFrane, S.A., (2014). Accurate Hf isotope determinations of complex zircons using the "laser ablation split stream" method. Geochemistry, Geophysics, Geosystems, 15(1), 121-139.

Froude, D. O., Ireland, T.R., Kinny, P.D., Williams, I.S., Compston, W., Williams, I.R., and Myers, J.S. (1983). Ion microprobe identifcation of 4,100 $\pm 4,200$ Myr-old terrestrial zircons. Nature, 304, 616-618.

Grange, M.L., Wilde, S.A., Nemchin, A.A., and Pidgeon, R.T. (2010). Proterozoic events recorded in quartzite cobbles at Jack Hills, Western Australia: New constraints on sedimentation and source of> 4Ga zircons. Earth and Planetary Science Letters 292(1), 158-169.

Griffin, W.L., Belousova, E.A., O'Neill, C.O., O'Reilly, S.Y., Malkovets, V., Pearson, N.J., Spetsius, S. and Wilde, S.A., 2014. The world turns over: Hadean-Archean crust-mantle evolution. Lithos, 189 , pp.2-15.

Grimes, C.B., John, B.E., Kelemen, P.B., Mazdab, F., Wooden, J.L., Cheadle, M.J., Hanghøj, K., Schwartz, J.J. (2007). The trace element chemistry of zircons from oceanic crust: a method for distinguishing detrital zircon provenance. Geology 35, 643-646 
Grimes, C.B., Wooden, J.L., Cheadle, M.J., John, B.E. (2015). “Fingerprinting” tectono-magmatic provenance using trace elements in igneous zircon. Contrib. Mineral. Petrol., 170, 1-26.

Harrison T.M., Blichert-Toft J., Müller W., Albarède F., Holden P. and Mojzsis S. J. (2005). Heterogeneous Hadean hafnium: evidence of continental crust by 4.4-4.5 Ga. Science 310, 19471950.

Harrison T.M., Schmitt A.K., McCulloch M. T. and Lovera O.M. (2008). Early ( $\geq 4.5 \mathrm{Ga}$ ) formation of terrestrial crust: $\mathrm{Lu}-\mathrm{Hf}, \delta^{18} \mathrm{O}$, and Ti thermometry results for Hadean zircons. Earth Planet. Sci. Lett. 268, 476-486.

Hawkesworth, C.J., Kemp, A.I.S. (2006) Using hafnium and oxygen isotopes in zircons to unravel the record of crustal evolution, Chemical Geology 226, 144-162.

Hiess, J., Bennett, V.C., Nutman, A.P., Williams, I.S. (2011). Archaean fluid-assisted crustal cannibalism recorded by low $\delta 18 \mathrm{O}$ and negative $\varepsilon \mathrm{Hf}(\mathrm{T})$ isotopic signatures of West Greenland granite zircon. Contributions to Mineralogy and Petrology 161 (6), 1027-1050

Holden P., Lanc P., Ireland T. R., Harrison T. M., Foster J. J., and Bruce Z. (2009). Massspectrometric mining of Hadean zircons by automated SHRIMP multi-collector and singlecollector U/Pb zircon age dating: the first 100,000 grains. International Journal of Mass Spectrometry 286(2), 53-63.

Hopkins, M. Harrison, T.M. Manning, C.E. (2010). Constraints on Hadean geodynamics from mineral inclusions in >4 Ga zircons, Earth Planet. Sci. Lett. 298, 367-376

Hopkins, M., Harrison, T.M., \& Manning, C.E. (2008). Low heat flow inferred from > 4 Gyr zircons suggests Hadean plate boundary interactions. Nature 456 (7221), 493-496.

Hoskin P.W.O., Ireland T.R. (2000) Rare earth element chemistry of zircon and its use as a provenance indicator. Geology 28, 627-630

Hoskin, P.W.O. (2005). Trace-element composition of hydrothermal zircon and the alteration of Hadean zircon from the Jack Hills , Australia. Geochim. Cosmochim. Acta 69, 637-648.

Hoskin, P.W.O. and Schaltegger, U. (2003). The composition of zircon and igneous and metamorphic petrogenesis, Reviews in mineralogy and geochemistry 53 (1), 27-62

Kamber, B.S., Whitehouse, M.J., Bolhar, R., \& Moorbath, S. (2005). Volcanic resurfacing and the early terrestrial crust: Zircon U-Pb and REE constraints from the Isua Greenstone Belt, southern West Greenland. Earth Planet Sci Lett 240 (2), 276-290.

Kamber, B.S. (2015). The evolving nature of terrestrial crust from the Hadean, through the Archaean, into the Proterozoic. Precambrian Research Precambrian Research 258, 48-82.

Kemp, A.I.S., Wilde, S.A., Hawkesworth, C.J., Coath, C.D., Nemchin, A., Pidgeon, R.T., Vervoort, J.D., DuFrane, S.A. (2010). Hadean crustal evolution revisited: New constraints from Pb-Hf isotope systematics of the Jack Hills zircons. Earth Planet. Sci. Lett. 296. 45-56.

Kinny P.D. and Nutman A.P. (1996). Zirconology of the Meeberrie gneiss, Yilgarn Craton, Western Australia: an early Archaean migmatite. Precambrian Research 78(1), 165-178.

Kinny P., Williams I., Froude D., Ireland T., and Compston W. (1988). Early Archaean zircon ages from orthogneisses and anorthosites at Mount Narryer, Western Australia. Precambrian Research 38(4), 325-341. 
Kramers, J.D. (2007). Hierarchical Earth accretion and the Hadean eon. Journal of the Geological Society $164,3-17$.

Ludwig, K.R. (1998). On the treatment of concordant uranium-lead ages. Geochimica et Cosmochimica Acta 62, 665-676.

Maas R., Kinny P. D., Williams I. S., Froude D. O., and Compston W. (1992) The Earth's oldest known crust: a geochronological and geochemical study of 3900-4200 Ma old detrital zircons from Mt. Narryer and Jack Hills, Western Australia. Geochimica et Cosmochimica Acta 56(3), 12811300 .

Menneken, M., Nemchin, A.A., Geisler, T., Pidgeon, R.T., Wilde S.A. (2007). Hadean diamonds in zircon from Jack Hills, Western Australia. Nature 448, 917-929.

Mojzsis S.J., Harrison T.M., Pidgeon R.T.,(2001) Oxygen-isotope evidence from ancient zircons for liquid water at the Earth's surface 4300 Ma ago, Nature 409, 178-181.

Muehlenbachs, K., and R. N. Clayton (1976), Oxygen isotope composition of the oceanic crust and its bearing on seawater, J. Geophys. Res., 81(23), 4365-4369

Myers J.S. (1993) Precambrian Tectonic History of the West Australian Craton and Adjacent Orogens. Annual Review of Earth and Planetary Sciences 21, 453-485.

Myers, J.S. and Williams I.R. (1985) Early Precambrian crustal evolution at Mount Narryer, Western Australia. Precambrian research 27(1-3), 153-163.

Næraa, T., Scherstén, A., Rosing, M.T., Kemp, A.I.S., Hoffmann, J.E., Kokfelt, T.F. \& Whitehouse, M.J. (2012). Hafnium isotope evidence for a transition in the dynamics of continental growth 3.2 Gyr ago. Nature 485, 627-630.

Nelson, D.R., B.W. Robinson, and J.S. Myers (2000), Complex geological histories extending for 4.0 Ga deciphered from xenocryst zircon microstructures, Earth Planet. Sci. Lett., 181, 89-102.

Nemchin, A.A. and Cawood, P.A., 2005. Discordance of the U-Pb system in detrital zircons: implication for provenance studies of sedimentary rocks. Sedimentary Geology, 182, 143-162

Nemchin, A., Pidgeon, R., and Whitehouse M. (2006). Re-evaluation of the origin and evolution of> 4.2 Ga zircons from the Jack Hills metasedimentary rocks. Earth and Planetary Science Letters 244(1), 218-233.

Nemchin, A.A., Whitehouse, M.J., Menneken, M., Geisler, T., Pidgeon, R.T., Wilde, S.A. (2008). A light carbon reservoir recorded in zircon-hosted diamond from the Jack Hills. Nature 454, 92-95.

Nutman A. P. Comment on "Zircon thermometer reveals minimum melting conditions on earliest Earth". Science 311, 779b (2006)

Peck, W.H., Valley, J.W., Wilde, S.A., \& Graham, C.M. (2001) Oxygen isotope ratios and rare earth elements in 3.3 to 4.4 Ga zircons: Ion microprobe evidence for high delta O-18 continental crust and oceans in the Early Archean. Geochim. Cosmochim. Acta 65 (22), 4215-4229.

Pidgeon, R.T., Nemchin, A.A., Whitehouse, M.J. (2017). The effect of weathering on U-Th-Pb and oxygen isotope systems of ancient zircons from the Jack Hills, Western Australia. Geochimica et Cosmoschimica Acta 197, 142-166.

Reimink, J.R., Chacko, T., Stern, R.A., Heaman, L.M. (2014). Earth's earliest evolved crust generated in an Iceland-like setting. Nature Geoscience 7, 529-533 
Reimink, J.R., Davies, J.H.F.L., Chacko, T., Stern, R.A., Heaman, L.M., Sarkar, C., Schaltegger, U., Creaser, R.A., and Pearson. D.G. (2016). No evidence for Hadean continental crust within Earth's oldest evolved rock unit. Nature Geoscience 9, 777-780

Schärer, U.; Allègre, C.J. (1985), "Determination of the age of the Australian continent by single-grain zircon analysis of Mt Narryer metaquartzite". Nature, 315 (6014): 52-55.

Shirey, S.B., Kamber, B.S., Whitehouse, M.J., Mueller, P.A. \& Basu, A.R. (2008). A review of the isotopic and trace element evidence for mantle and crustal processes in the Hadean and Archean: Implications for the onset of plate tectonic subduction. In: When did plate tectonics start on Earth? Condie, K.C. \& Pease, V.L. eds, Geological Society of America, Memoir 440, 1-29.

Spaggiari, C.V., 2007a. The Jack Hills greenstone belt, Western Australia: Part 1: Structural and tectonic evolution over> 1.5 Ga. Precambrian Research, 155(3), pp.204-228.

Spaggiari, C.V., Pidgeon, R.T. and Wilde, S.A., 2007b. The Jack Hills greenstone belt, Western Australia: part 2: lithological relationships and implications for the deposition of $\geq 4.0 \mathrm{Ga}$ detrital zircons. Precambrian Research, 155(3), pp.261-286.

Thern E. R. and Nelson D. R. (2012) Detrital zircon age structure within ca. 3Ga metasedimentary rocks, Yilgarn Craton: Elucidation of Hadean source terranes by principal component analysis. Precambrian Research 214, 28-43.

Trail D., Mojzsis S.J., Harrison T.M., Schmitt A.K., Watson E.B. and Young E.D. (2007) Constraints on Hadean zircon protoliths from oxygen isotopes, REEs and Ti-thermometry.Geochem. Geophys. Geosyst. 8, Q06014

Trail D.,Watson B.E. and Tailby N.D. (2013) Insights into the Hadean Earth from Experimental Studies of Zircon., Journal of the geological Society of India 81, 605-636

Ushikubo T., Kita N.T., Cavosie A.J., Wilde S.A., Rudnick R.L. and Valley, J.W. (2008) Lithium in Jack Hills zircons: Evidence for extensive weathering of Earth's earliest crust. Earth Planet Sci. Lett. 272, 666-676.

Valley J.W., Peck W.H., King E.M. and Wilde S.A. (2002). A cool early Earth. Geology 30, 351-354.

Valley, J.W., 2003. Oxygen isotopes in zircon. In: Hanchar, J.M., Hoskin, P.W.O. (Eds.), Zircon. Reviews in Mineralogy and Geochemistry., vol. 53, pp. 343-385.

Valley J.W., Cavosie, A.J., Ushikubo, T., Reinhard, D.A., Lawrence, D.F., Larson, D.J., Clifton, P.H., Kelly, T.F., Wilde, S.A., Moser, D.E., Spicuzza, M.J.(2014). Hadean age for a post-magma-ocean zircon confirmed by atom-probe tomography. Nature Geoscience, 7(3): 219-223.

Vavra, G., Gebauer, D., Schmid, R., (1996). Multiple zircon growth and recrystallization during polyphase Late Carboniferous to Triassic metamorphism in granulites of the Ivrea Zone (Southern Alps): an ion microprobe (SHRIMP) study. Contributions to Mineralogy and Petrology 122, 337358

Vavra, G. Schmid, R. Gebauer, D. (1999). Internal morphology, habit and U-Th-Pb microanalysis of amphibolite-to-granulite facies zircons: geochronology of the Ivrea Zone (Southern Alps). Contributions to Mineralogy and Petrology 134, 380-404

Watson, E.B. and Harrison, T.M. (2005). Zircon thermometer reveals minimum melting conditions on earliest Earth. Science 308, 841-844. 
Wiedenbeck, M., Hanchar, J., Peck, W.H., Sylvester, P., Valley, J., Whitehouse, M.J., Kronz, A., Morishita, Y. Nasdala, L. \& twenty one others (2004). Further characterization of the 91500 zircon crystal. Geostandards and Geoanalytical Research 28, 9-39.

Wilde S.A., Valley J.W., Peck W.H., Graham, C.M. (2001) Evidence from detrital zircons for the existence of continental crust and oceans on the Earth 4.4 Gyr ago, Nature 409 175-177.

Wyche S., Nelson D., and Riganti A. (2004) 4350-3130 Ma detrital zircons in the Southern Cross Granite-Greenstone Terrane, Western Australia: implications for the early evolution of the Yilgarn Craton. Australian Journal of Earth sciences 51(1), 31-45.

Zeh, A., Stern, R. A., and Gerdes, A. (2014). The oldest zircons of Africa-Their U-Pb-Hf-O isotope and trace element systematics, and implications for Hadean to Archean crust-mantle evolution. Precambrian Research 241, 203-230. 
Figure captions

Figure 1. (a) Schematic inverse (Tera-Wasserburg) concordia diagram showing the effect of analytical uncertainty on interpretation of ages. A single analyses with ${ }^{207} \mathrm{~Pb} /{ }^{206} \mathrm{~Pb}$ age $\left(\mathrm{t}_{\text {meas }}\right)$ of $4000 \mathrm{Ma}$ and an uncertainty in $\mathrm{U} / \mathrm{Pb}$ ratio of $\pm 2 \%$ is shown, concordant at the upper limit. Two chords are drawn though the lower uncertainty limit (4\% discordant), illustrating possible crystallisation $\left(\mathrm{t}_{1}\right)$ and $\mathrm{Pb}$-loss ( $t_{2}$ ) age pairs. (b) General version of the $t_{1}-t_{2}$ relationships shown in (a) for measured ${ }^{207} \mathrm{~Pb} /{ }^{206} \mathrm{~Pb}$ ages $4200 \mathrm{Ma}$ (dashed lines) and $4000 \mathrm{Ma}$ (solid lines) for $\mathrm{U} / \mathrm{Pb}$ displacement from concordia of $1 \%, 2 \%$ and $4 \%$.

Figure 2 - Map of the Yilgarn Craton in south-western Australia showing the major terrane subdivisions, greenstone belts (green) and the locations of the Jack Hills Figure 3 - Representative selection of zircon internal structures, excluding those that can be considered to be secondary features: (a, b and c) fine concentric zoning representing magmatic growth, tip of grain (c) also shows cross-bedded zoning that can be interpreted as late magmatic or metamorphic; (d, e and f) thick concentring bands that can represent magmatic crystallisation or formation in late magmatic melts and/or fluids, tip of grain (f) also has cross-bedded zoning; ( $\mathrm{g}$, $\mathrm{h}$ and i) show various combinations of concentric, sector and cross-bedded zoning, which points to a possibility of multiple growth episodes either within a single magmatic or metamorphic event or separate events; ( $\mathrm{j}, \mathrm{k}$ and $\mathrm{l}$ ) sector zoning common in high grade metamorphic rocks; ( $\mathrm{m}, \mathrm{n}$ and o) complex zoning indicative of multiple growth episodes

Figure 4. Combined histogram and probability density curves (PDC) of ages from the subset of the >3900 Ma Jack Hills zircon population for which multiple analyses have been reported (140 grains). (a) Individual unfiltered ${ }^{207} \mathrm{~Pb} /{ }^{206} \mathrm{~Pb}$ ages $(\mathrm{n}=451)$, together with PDC's of the population remaining after filtering of analyses that are $<10 \%$ and $<2.5 \%$ discordant. (b) PDC resulting from restricting plotted ages to grains from which concordia ages (Ludwig, 1998) on two or more analyses have been obtained, together with oldest single concordant ${ }^{207} \mathrm{~Pb} /{ }^{206} \mathrm{~Pb}$ ages. (c) As (c) but plotting results from concordia ages only; the red dashed line shows the PDP resulting from selection of $2 \sigma$ age 
uncertainties, while the purple line is calculated using 95\% confidence limit for those analyses where

this is offered by the Isoplot algorithm. (d) As (c) but restricting concordia ages to those obtained from 3 or more analyses.

Figure 5. Conventional concordia plots of (a) individual unfiltered ${ }^{207} \mathrm{~Pb} /{ }^{206} \mathrm{~Pb}$ ages $(\mathrm{n}=451)$ and $(\mathrm{b})$ concordia ages derived from grains subjected to multiple spot analyses, differentiated into $n \geq 2$ and $n$ $\geq 3$. Error ellipses are $2 \sigma$.

Figure 6. Plot of analytical uncertainties $(1 \sigma \%)$ in reported ${ }^{207} \mathrm{~Pb} /{ }^{206} \mathrm{~Pb}$ ratios against those in ${ }^{206} \mathrm{~Pb} /{ }^{238} \mathrm{U}$ ratios for the investigated data set, colour/symbol coded to the data sources. Panel (a) shows the complete set of data $(n=451)$ while panel $(b)$ is restricted to analyses that are concordant within $2 \sigma$ error $(n=257)$.

Figure 7. Oxygen isotope data from Jack Hills zircon expressed as $\delta^{18} \mathrm{O}_{\mathrm{V}-\mathrm{SMOw}}$ in \%o plotted against the concordia age ( $\mathrm{n} \geq 2$ and $\mathrm{n} \geq 3$ ) or single oldest concordant age determined from multiple spot analyses presented in this study. The fields of zircon in equilibrium with mantle $\left(\delta^{18} \mathrm{O}=5.3 \pm 0.6 \%\right.$, 2 SD; Valley, 2003) and of zircon considered likely to have been derived from melts influenced by Archaean supracrustal rocks $\left(6.3 \% 0 \delta^{18} \mathrm{O}<7.5 \%\right.$; Cavosie et al., 2005) are shown as horizontal coloured bars.

Figure 8. Lu-Hf evolution diagram showing the $\varepsilon_{\mathrm{Hf}}(\mathrm{t})$ values from zircon determined by Kemp et al. (2010) replotted using the concordia age ( $\mathrm{n} \geq 2$ and $\mathrm{n} \geq 3$ ) or single oldest concordant age determined from multiple spot analyses presented in this study (error boxes) together with remaining data from the Kemp et al. (2010) study plotted using the ${ }^{207} \mathrm{~Pb} /{ }^{206} \mathrm{~Pb}$ age concurrently determined during the $\mathrm{Hf}$ isotope analysis (error crosses). The inset diagram compares the concurrent ${ }^{207} \mathrm{~Pb} /{ }^{206} \mathrm{~Pb}$ age with the multiple analysis concordia or single oldest concordant age for the eight zircon grains highlighted in the main plot.

Figure 9. Comparison of the age spectra of $>3.8$ Ga grains from the Jack Hills presented by (a) Holden et al. (2009), (b) Cavosie et al. (2004), and (c) this study, concordia ages from >2 analyses. Grey 
vertical bars across all plots highlight the five most significant age peaks from the filtering method applied in this study (c). See text for discussion.

Figure 10. Comparison of oxygen isotope data for the Jack Hills zircon suite by (a) Cavosie et al. (2005) with (b) the filtered data set from this study (as Fig. 7). See text for discussion.

Figure 11. Comparison of $\varepsilon_{\mathrm{Hf}}(\mathrm{t})$ data presented by (a) Harrison et al. $(2005,2008)$ with (b) the filtered data set from this study based on the data presented by Kemp et al. (2010). See text for discussion. 


\section{Vitae}

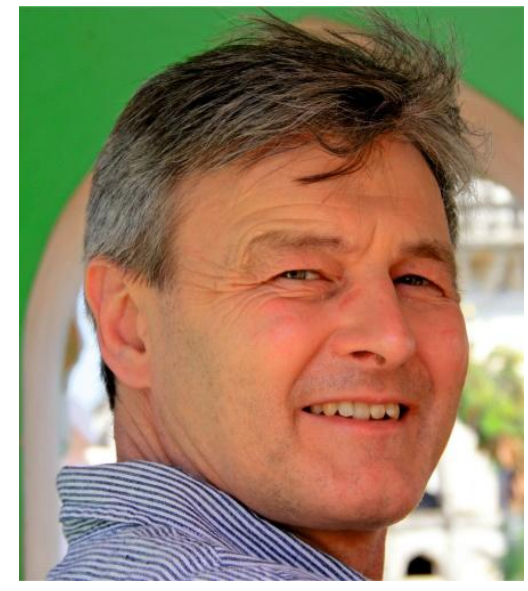

Martin Whitehouse is Professor of Isotope Geology at the Swedish Museum of Natural History in Stockholm and director of the Nordic ion microprobe facility, NordSIMS. He completed his DPhil. at the University of Oxford in 1987, investigating crustal growth and reworking in the Neoarchean Lewisian Complex of NW Scotland. Following post-doctoral fellowships at USGS in Menlo Park and the Mineralogical Geological Museum is Oslo, he returned to Oxford in 1990 as a Royal Society research fellow before taking up his current position in 1996. His primary research tools are geochronology, stable and radiogenic isotopes applied to a wide range of topics including Precambrian crustal evolution, early terrestrial surface environments and, more recently, lunar and martian studies.

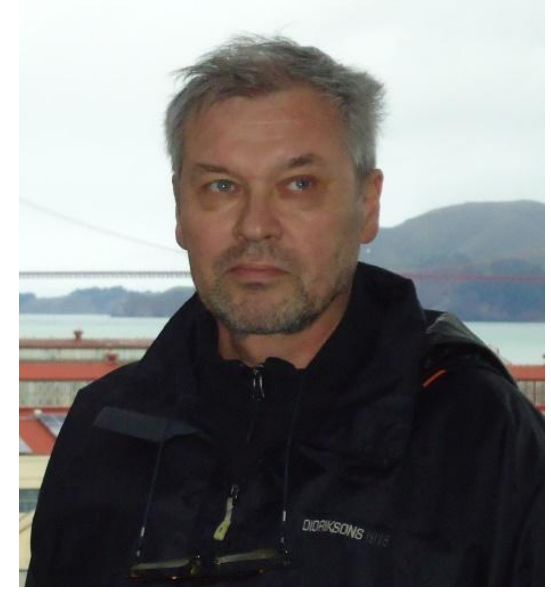

Alexander Nemchin completed his $\mathrm{PhD}$ on the evolution of late Archaean Darling Range batholith at Curtin University Australia in 1996. For the last 20 years he has worked at the Western Australian School of Mines investigating U-Pb system in accessory minerals such as zircon in a variety of magmatic and metamorphic rocks as well as detrital zircon populations extracted from the sedimentary rocks around the world. His recent interests include isotope studies of oldest zircon populations in Western Australia as well as the samples from Moon and Mars. 
Robert Pidgeon completed his PhD at the Australian National University in 1965. From 1965 to 1968 he undertook post doctoral fellowships at the California Institute of Technology and the Swiss Federal Institute of Technology (ETH). From 1968-1976 he was Senior Lecturer and foundation leader of the Isotope Geology Unit of the Scottish Universities Research and Reactor Centre in East Kilbride. He was a Senior Research Fellow in the Research School of Earth Sciences, Australian National University, from 1976- 1978 and from 1978-1982 was Director of the Nuclear Codes Section in the Commonwealth Government of Australia. From 1982-2001 he was an Associate Professor and then Professor of Geology at Curtin University and is currently an Adjunct Professor at Curtin University. Over the years he has undertaken geochronological research on a variety of geological problems concentrating on the application of zircon U-Pb systems. 
Figure 10.6
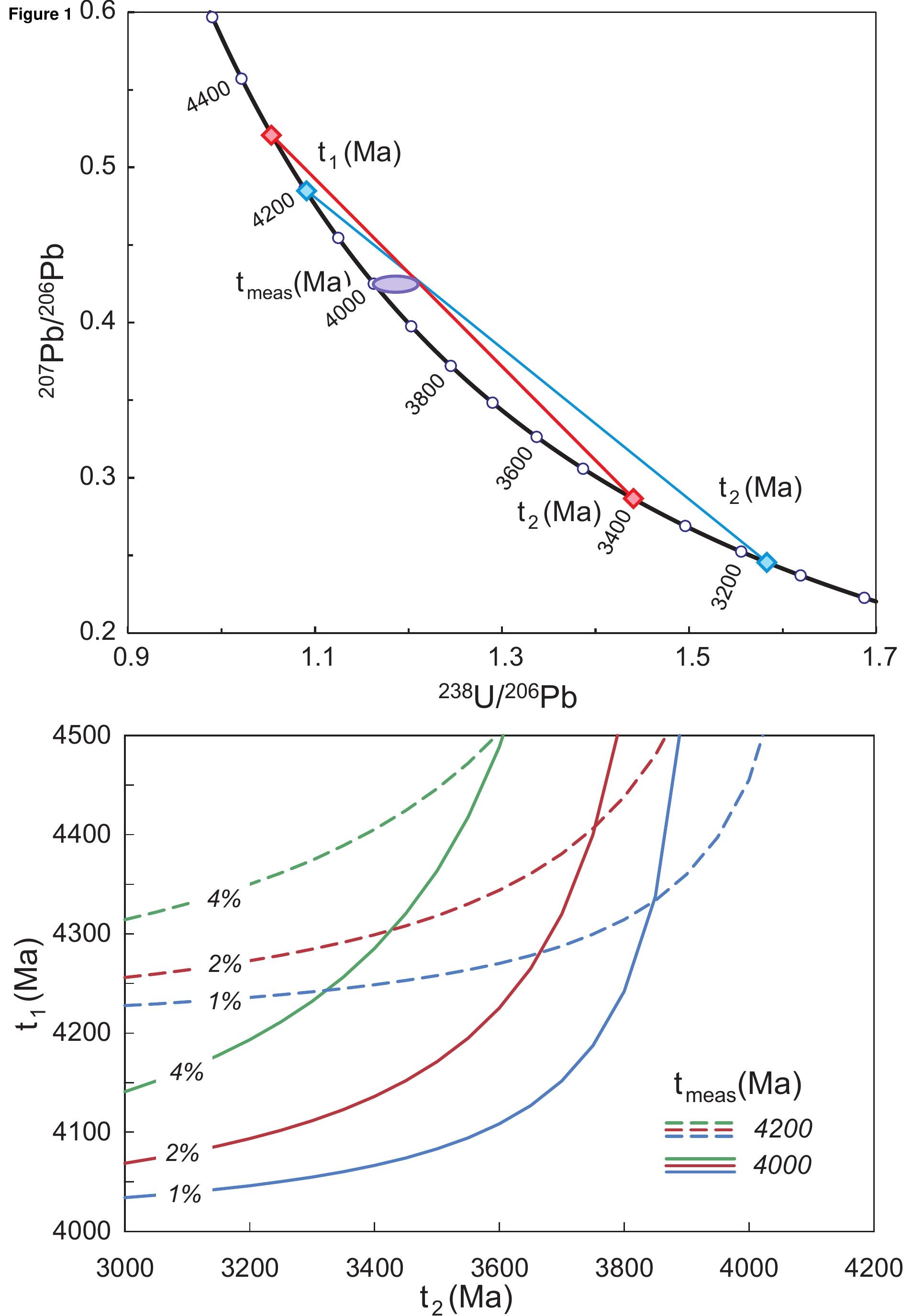


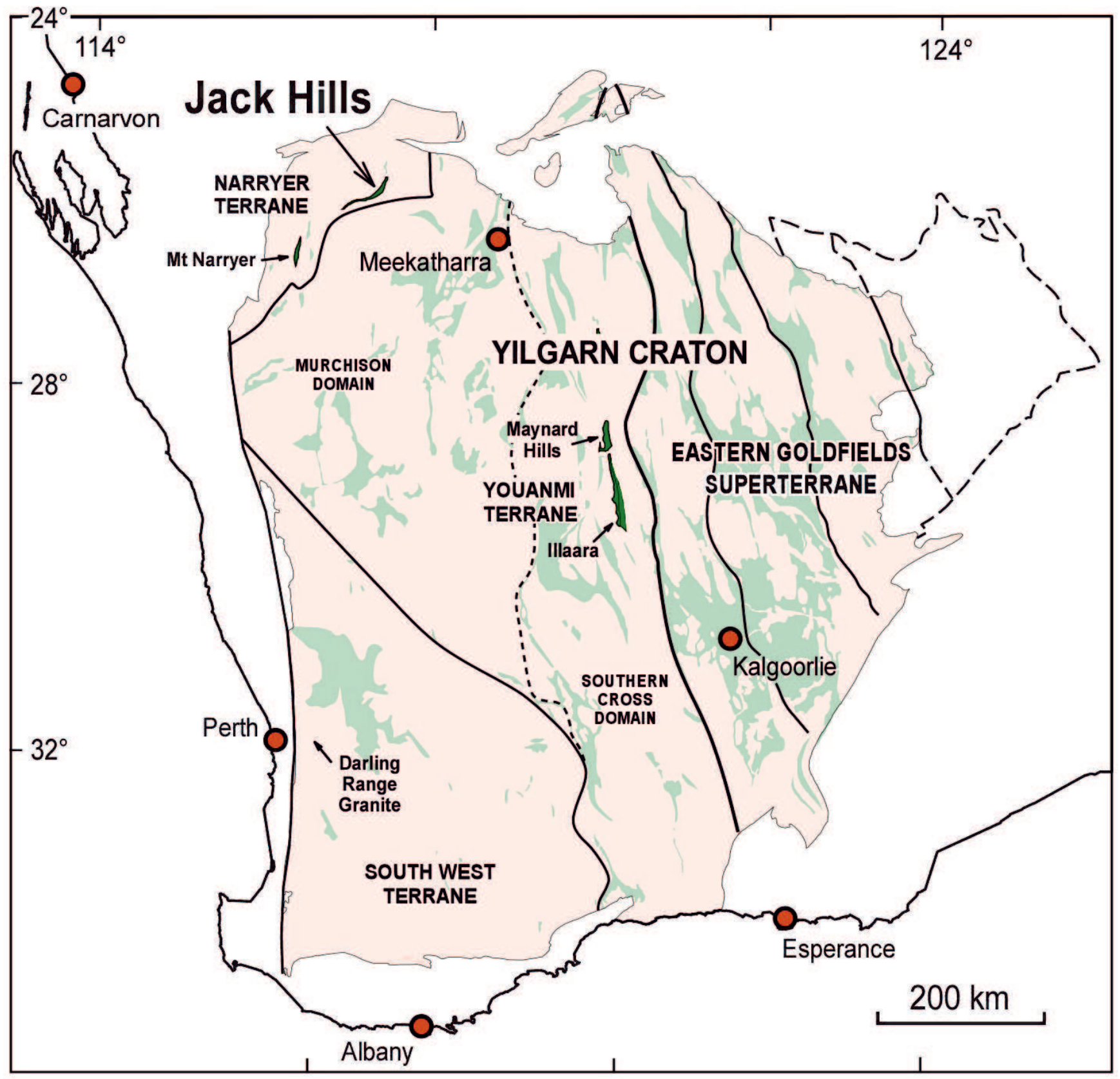




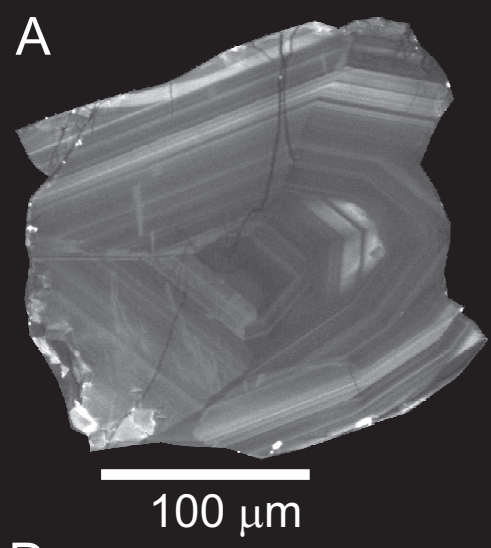

B
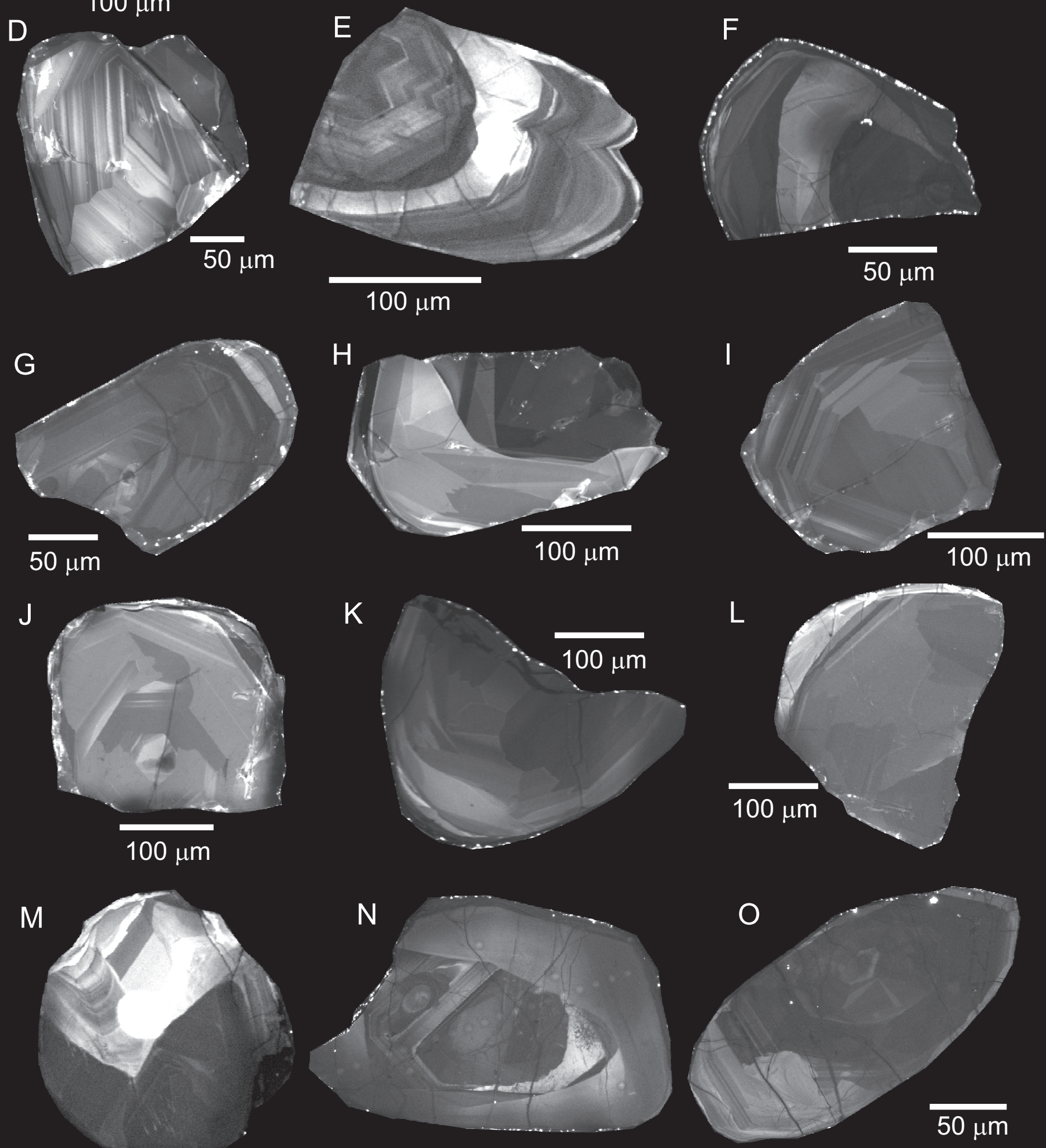

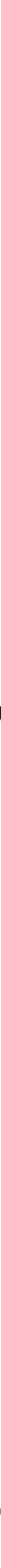
Figure 5
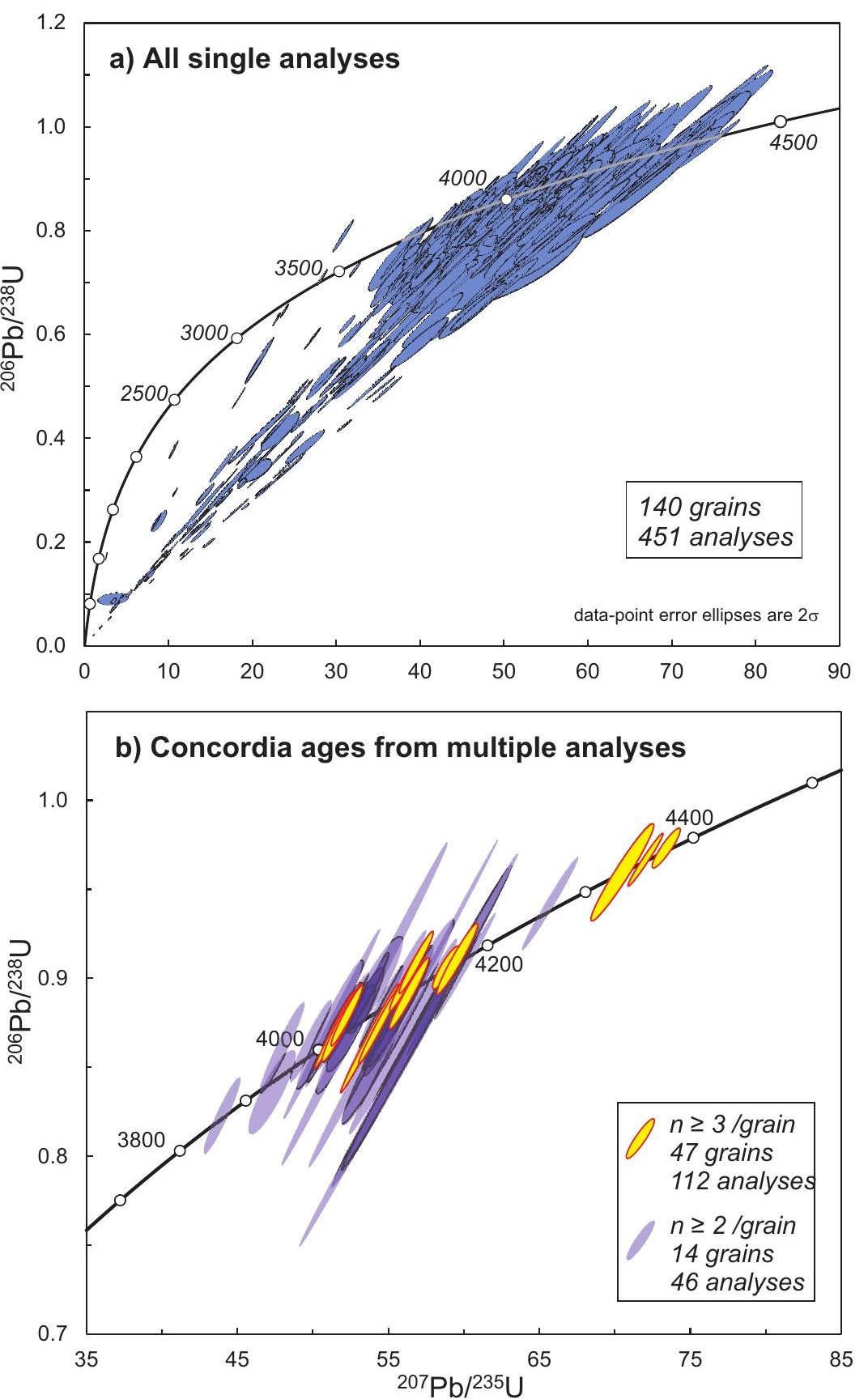


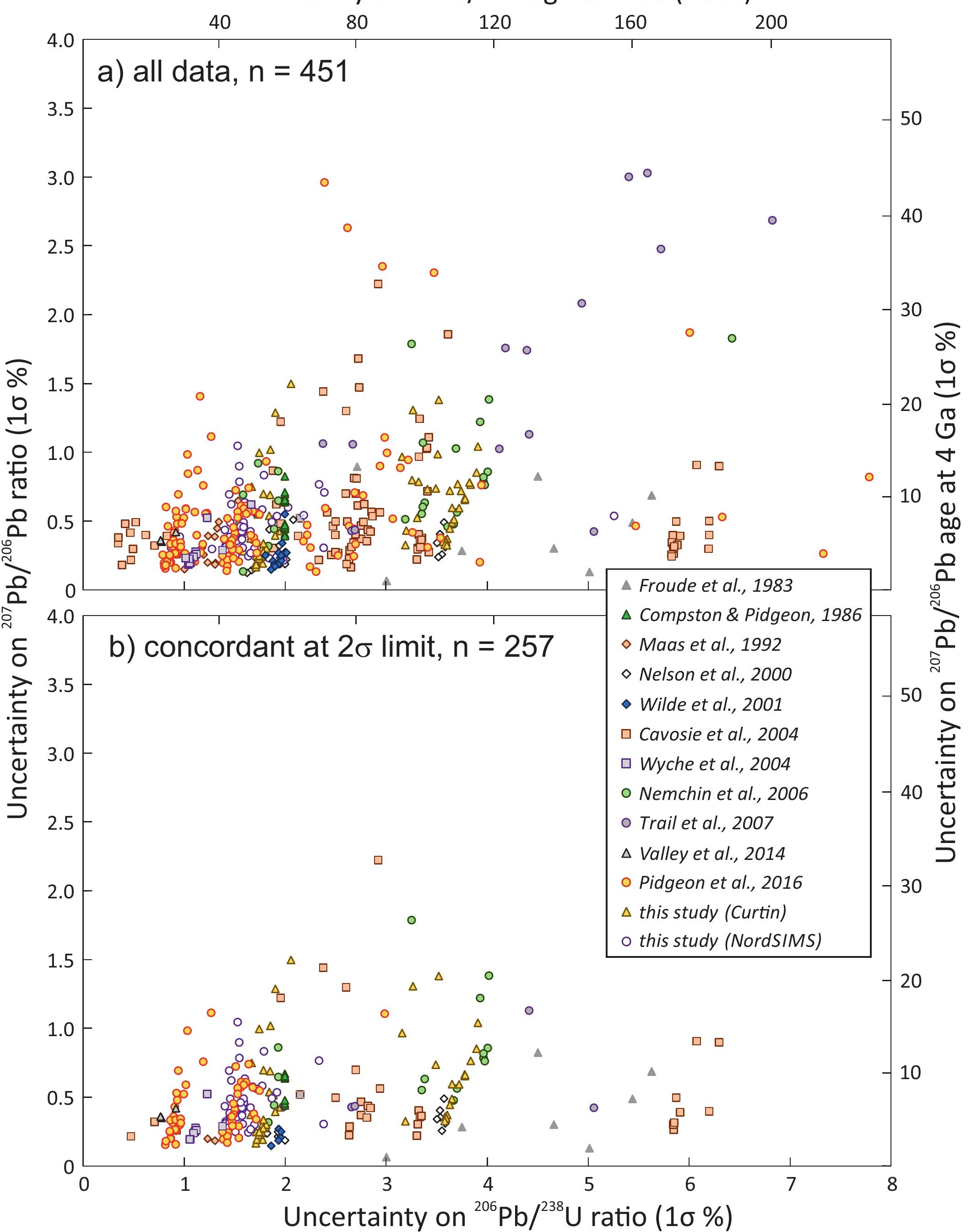




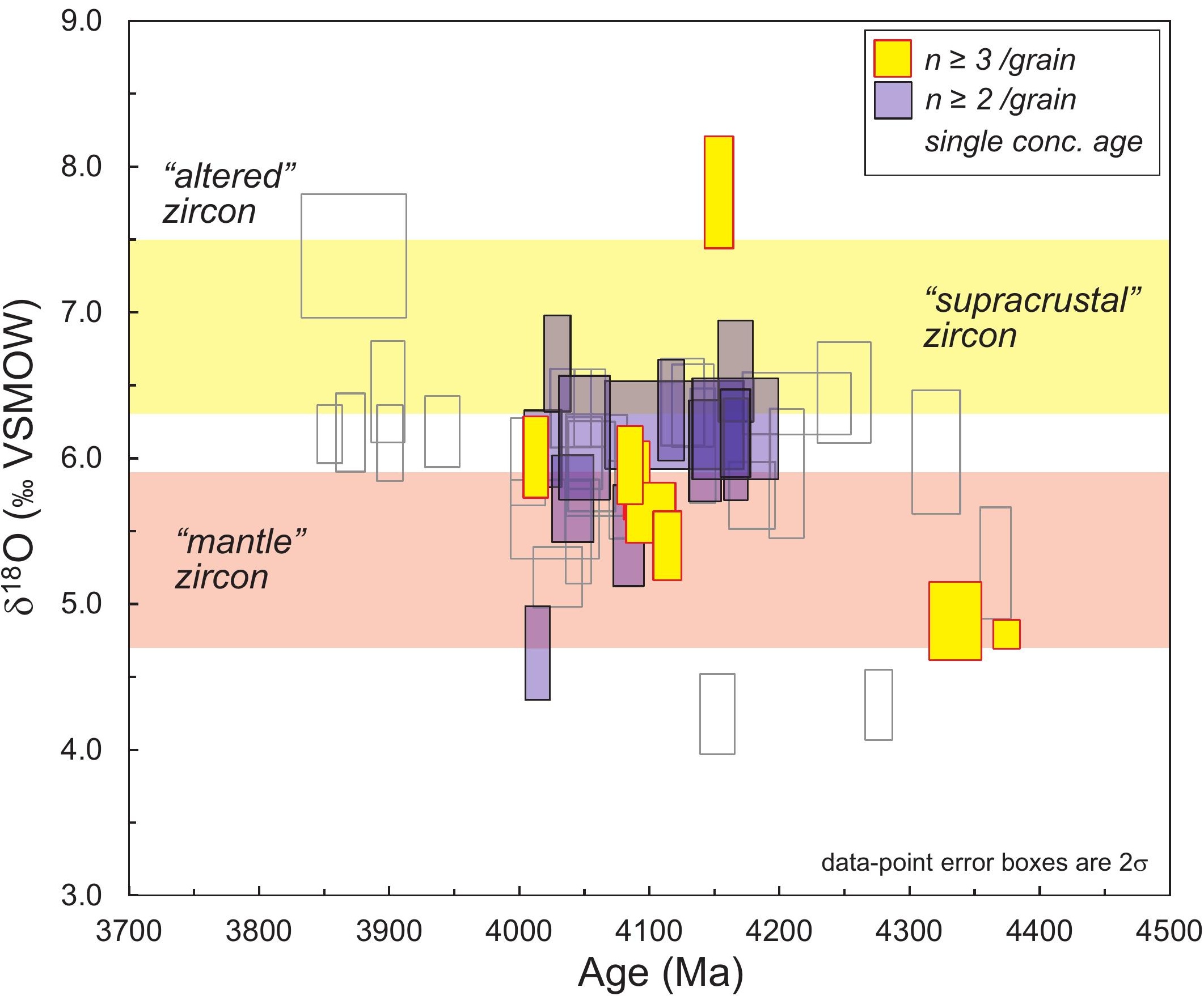




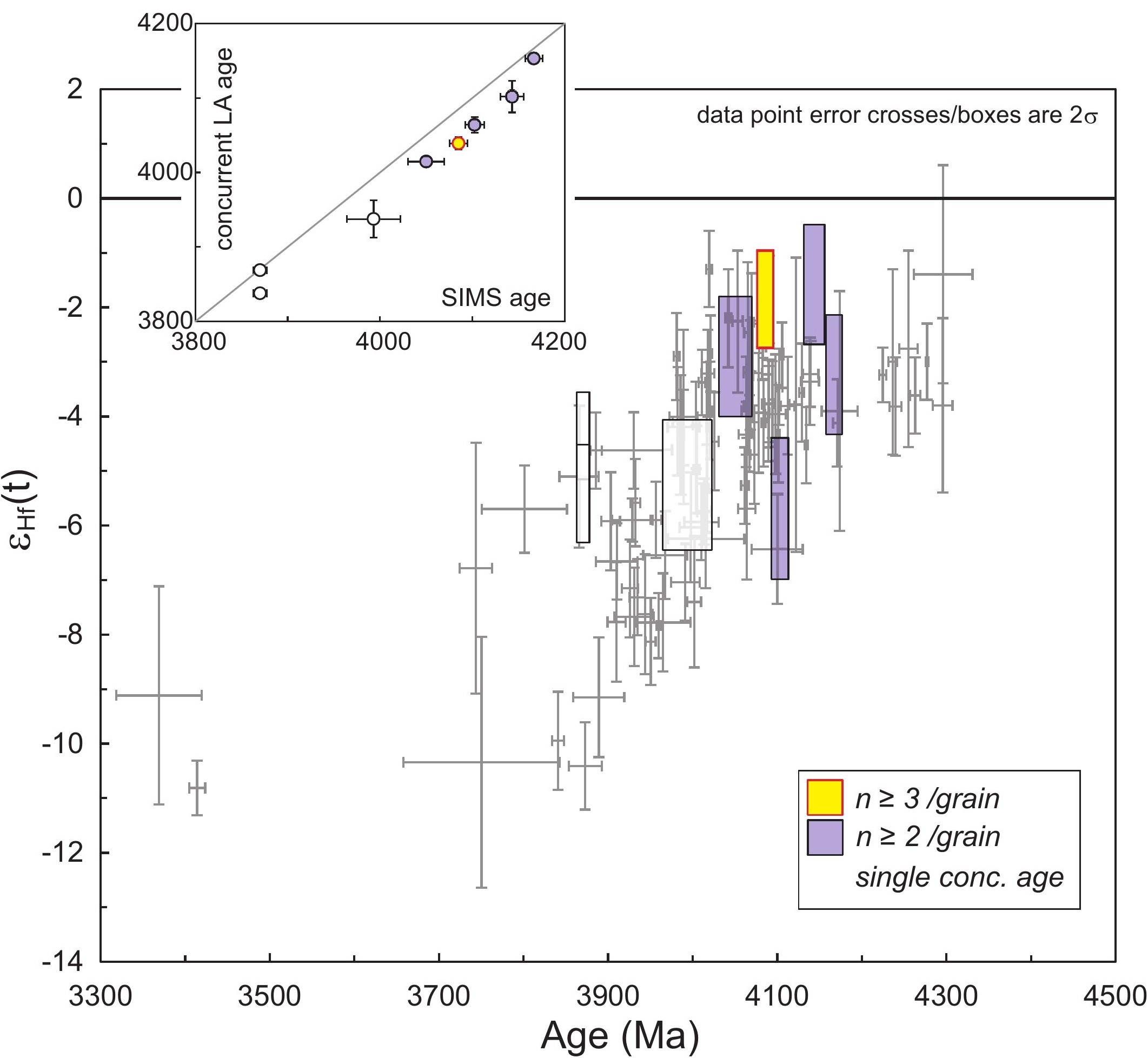


Figure 11

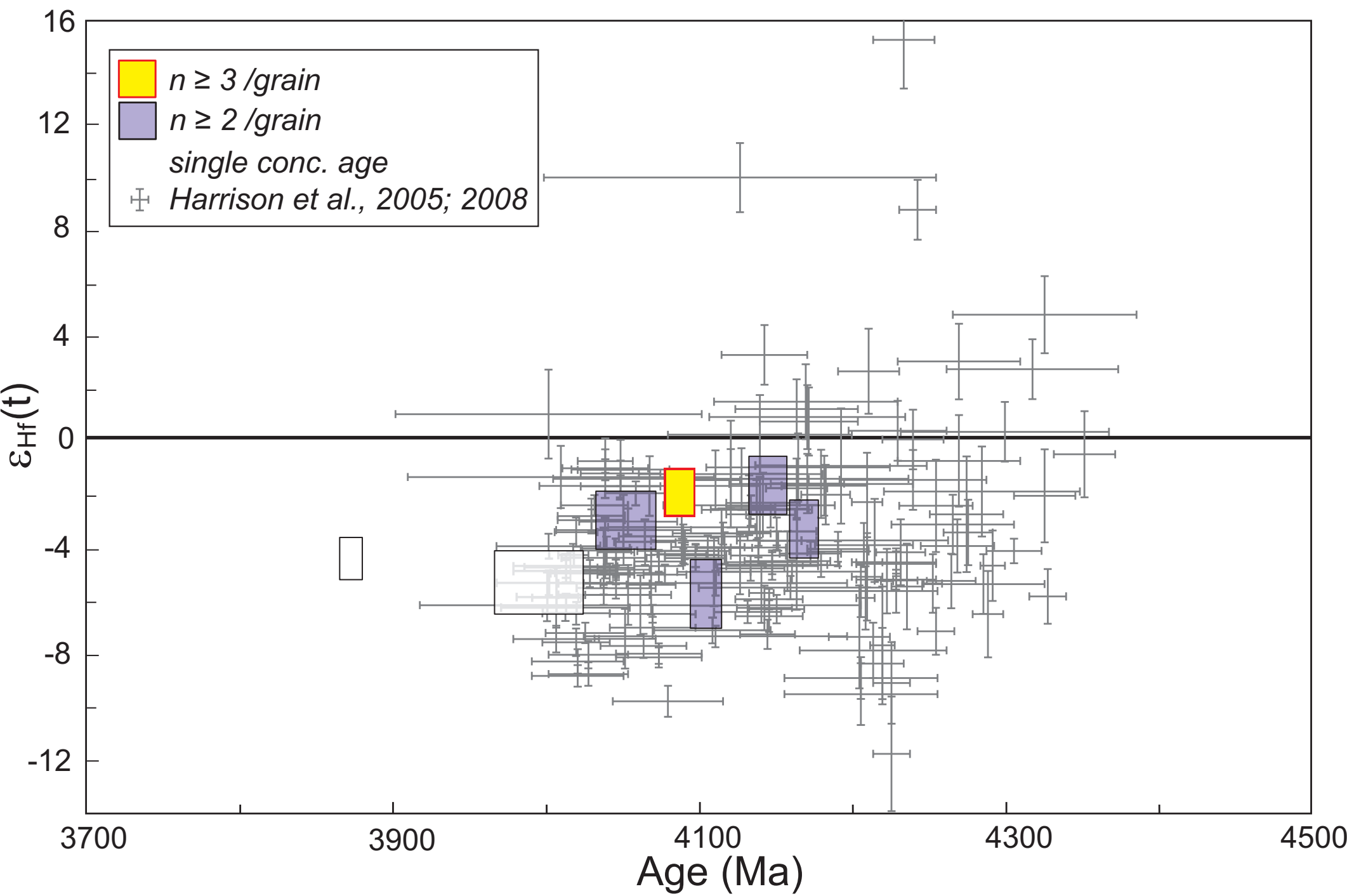

